\title{
Evidence Based Problem Solving in General Practice: The Foreign Body in the Nose
}

\author{
Lt Col AJ Leach \\ MB, ChB, MSc (Med), MRCGP, DRCOG, DFFP, Dip IMC RCSEd, RAMC \\ Senior Medical Officer
}

\section{Medical Reception Station, Dhekelia, British Forces Post Office 58 \\ Email:leachaj@yahoo.com}

SUMMARY: This paper reviews the efficacy of six different methods of removal of foreign bodies from the nose. Removal with a Fogarty catheter, the "Ambu Bag $^{\circledR}$ method, nebulised adrenaline, tissue adhesive, forceps and direct suction are considered. No method appears to be obviously superior to any other.

\section{Introduction}

Nasal foreign bodies are relatively uncommon and usually occur in children. One study demonstrated that $3 \%$ of ENT admissions to a Paris hospital were for nasal foreign bodies (1). Data from the Medical Reception Station Dhekelia reveals that five children have had foreign bodies removed over the last year. All these were successfully removed by a general practitioner in the treatment room. The commonest foreign bodies encountered are beads, peanuts, foam rubber, parts of toys and paper. Often the parent or other caregiver will have witnessed the child place the foreign body in the nose and thus they present within 24 hours of impaction. Some foreign bodies will have been in place for some months - they tend to be characterised by a foul odour from the nose often with a purulent nasal discharge. It is relatively rare for a child to present with a nasal foreign body above the age of 6 years, unless the patient has learning difficulties. Nasal foreign bodies in adults tend to be associated with trauma, thus they require extra care.

\section{Methods}

Discussions with colleagues revealed that they each have their favourite method of removing objects from within the nose. A "Children's Hospital" television programme showed a method new to me, namely the application of Cyanoacrylate (Histacryl) glue to a probe, which is then inserted into the nose with the hope that the foreign body would then attach to the probe. What is clear is that there is no consensus as to the most successful method. On this basis I undertook a pragmatic search for evidence of the best method. The search was pragmatic insofar most general practitioners would search easily accessible information, but would probably go no further unless further specific questions needed to be answered. Both MEDLINE and EMBASE databases were searched with the parameters Foreign Body, Nose and Human. In addition the Bandolier Evidence Based Medicine Internet site was searched (http://www.jr2.ox.ac.uk/bandolier/index.html). Eighteen articles were revealed, but only from MEDLINE and EMBASE - the search took about 20 minutes to complete. Similarly the Medical Reception Station Dhekelia library was searched for

Table 1

\begin{tabular}{|c|c|c|}
\hline Paper & Method of Removal & Comments \\
\hline $\begin{array}{l}\text { Nandapalan V and } \\
\text { McIlwain JC (3) }\end{array}$ & $\begin{array}{l}\text { Fogarty biliary catheter passed beyond the object, inflated and then } \\
\text { removed pushing the foreign body in front of the balloon. Nose } \\
\text { pre-instilled with two drops of lignocaine and two of ephedrine. } 25 \\
\text { successful cases described. }\end{array}$ & $\begin{array}{l}\text { The authors were able to remove objects that } \\
\text { were not accessible with probes or other } \\
\text { instruments. Minor side effects only described. }\end{array}$ \\
\hline Finkelstein JA (4) & $\begin{array}{l}\text { Patient placed in Trendelenburg position. Unobstructed nares } \\
\text { closed with a finger. Ambu bag place on mouth and rapidly } \\
\text { inflated. Allowed button } 1.5 \mathrm{~cm} \text { into nose to be expelled. } 3 \\
\text { successful cases described. }\end{array}$ & $\begin{array}{l}\text { Probably successful only if foreign body in } \\
\text { anterior part of nares. Alternative method is to } \\
\text { ask a parent to blow hard onto the child's open } \\
\text { mouth. }\end{array}$ \\
\hline Douglas AR (5) & $\begin{array}{l}\text { Nebulised Adrenaline }(2 \mathrm{ml} \text { of } 1: 1000) \text { given followed by nose } \\
\text { blowing by the child. Six successful cases described. }\end{array}$ & $\begin{array}{l}\text { Needs care as foreign body can move } \\
\text { backwards as well as forwards. Thus authors } \\
\text { only recommend that it be used if the size of } \\
\text { the foreign body is such that posterior } \\
\text { movement unlikely and that emergency } \\
\text { facilities available. }\end{array}$ \\
\hline $\begin{array}{l}\text { Hanson RM and } \\
\text { Stephens } M(6)\end{array}$ & $\begin{array}{l}\text { Cyanoacrylate glue assisted removal. Cyanoacrylate applied to cut } \\
\text { hollow plastic swab stick. Stick then pressed (under direct vision) } \\
\text { onto foreign body for } 60 \text { seconds. Removal of stick brings out } \\
\text { foreign body. } 94 \text { successful cases reported. }\end{array}$ & $\begin{array}{l}\text { Little skill by operator needed and often well } \\
\text { tolerated. Suitable for round foreign bodies } \\
\text { which are often difficult to grasp with forceps. } \\
\text { Technique can be used to remove foreign } \\
\text { bodies from the ear. }\end{array}$ \\
\hline $\begin{array}{l}\text { Francois M, Hamrioui } \\
\text { R and Narcy P and } \\
\text { Brownstein DR and } \\
\text { Hodge D }(1,7)\end{array}$ & $\begin{array}{l}\text { Use of forceps or hook under direct observation. } 68 \text { successful } \\
\text { cases reported by Francois and Hamrioui. }\end{array}$ & $\begin{array}{l}\text { Traditional method of removal. Often } \\
\text { successful if patient compliant. Requires access } \\
\text { to ENT type equipment. }\end{array}$ \\
\hline Jensen JH(8) & $\begin{array}{l}\text { Foreign Body removed by direct suction via a tube onto the foreign } \\
\text { body. } 30 \text { cases reported. }\end{array}$ & $\begin{array}{l}\text { Variation on using Cyanoacrylate on the end of } \\
\text { a probe. Appears technically more difficult } \\
\text { than using Cyanoacrylate. }\end{array}$ \\
\hline
\end{tabular}


any books or other relevant articles. One ENT book had reference to the removal of foreign bodies from the nose (less than one page), but no recommendation on the best method (2). Of the 18 articles revealed (including abstracts), 11 were thought to potentially answer the question "What is the best method of removing a nasal foreign body?"

Table 1 shows the methods of removal given in the various papers. What is clear from the descriptions is that the method employed was the one the attending doctor was most comfortable or skilled in employing. I could find no comparisons of the various methods in terms of success rate or complications. Most of the papers described the methods the authors had found successful with little or no information given about those cases in which method had been attempted and was unsuccessful. The lack of this important data prevents any meaningful comparison.

\section{Discussion}

In deciding which method to employ it is important to take into account the demeanour of the child. At most, two attempts can be made to remove the foreign body, although it is frequently one. Some papers describe how to restrain the child using either a blanket or special board with straps (7), to allow direct visualisation and removal. The possible psychological sequelae of restraint need to be balanced against the risk and cost of a general anaesthetic. The ENT Department is unlikely to see the child again, whereas the general practitioner will almost certainly treat the child in the future. In addition the attending doctor needs to take into account the risk of the foreign body moving posteriorly and then being inhaled. If the risk is assessed as being high, the child should be referred to a place where facilities exist for bronchoscopy.

A chronically impacted foreign body almost certainly requires onward referral to an ENT Department to allow for full examination of the nasal cavities. The classical picture is of a unilateral, purulent, fetid rhinorrhoea. Bilateral rhinorrhoea can exist if foreign bodies are present in both nares. Thus examination of the nose is required before diagnosing sinusitis or empirically prescribing antibiotics (which will never clear rhinorrhoea due to a foreign body).

Two papers describe the difficulties when button batteries, such as those used in watches or calculators are inserted into the noses $(9,10)$. Even after a very short time (3 hours) a greyish discharge was noted and after removal tissue necrosis apparent. Whilst a leaking battery will make matters worse, most cases occurred when the negative pole of a non-leaking battery was in contact with the nasal mucosa. In one case a septal perforation larger than the impacted battery was present within a week. The authors recommend urgent ENT referral to allow for removal and liberal irrigation of the affected area.

\section{Conclusion}

On the basis of the evidence, what should the general practitioner do when confronted with a child with a nasal foreign body? If chronically impacted, has caused damage inside the nose or is a potentially caustic, such as a battery, the child should be referred to an ENT surgeon. If acutely impacted and easily visible, the evidence does not point towards any method being superior to another. It is thus dependant upon the equipment available and the experience of the doctor. Most general practices do not have Fogarty biliary catheters and normally only a limited amount of ENT equipment. The application of Cyanoacrylate to a swab stick appears relatively successful and my personal experience of the Ambu Bag technique is that it has worked in five patients, although it was unsuccessful in three. One matter that is completely clear from those with practical experience with dealing with this problem - the success rate in general practice is wholly dependent upon the compliance and placidity of the patient, irrespective of the method of removal employed.

\section{REFERENCES}

1. Francois M, Hamrioui R, NARCy P. Nasal Foreign Bodies in Children. Eur Arch Otorhinolaryngol 1998; 225: 132134.

2. Logan Turner's Diseases of the Nose, Throat and Ear. Ed Maran AGD. Butterworth-Heinemann. 1988.

3. Nandapalan V, McIlwain JC. Removal of nasal foreign bodies with a Fogarty biliary balloon catheter. J Laryngol Otol 1994; 108: 758-760.

4. FinKELSTEIN JA. Oral Ambu-Bag insufflation to remove unilateral nasal foreign bodies. Am J Emerg Med 1996; 14(1): $57-58$

5. DoUgLAS AR. Use of nebulised adrenaline to aid expulsion of intra-nasal foreign bodies in children. J Laryngol Otol 1996; 110: 559-560.

6. HANSON RM, Stephens M. Cyanoacrylate-assisted foreign body removal from the ear and nose in children. $J$ Paediatr Child Health 1994; 30: 77-78.

7. BRownsteIn DR, Hodge D. Foreign Bodies of the eye, ear and nose. Pediatr Emerg Care 1988; 4(3): 215-218.

8. JENSEN JH. Technique for removing a spherical foreign body from the nose or ear. Ear, Nose, Throat J 1976; 55: 270-271.

9. Palmer O, Natarajan B, Johnstone A, Sheikh S. Button battery in the nose - an unusual foreign body. J Laryngol Otol 1994; 108: 871-872.

10. Tong MCF, VAn Hasselt CA, WoO JKS. The hazards of button batteries in the nose. J Otolaryngol 1992; 21(6): 458460. 